\title{
Influence of sex on chronic obstructive pulmonary disease risk and treatment outcomes
}

\author{
This article was published in the following Dove Press journal: \\ International Journal of COPD \\ 14 October 2014 \\ Number of times this article has been viewed
}

\author{
Shambhu Aryal' \\ Enrique Diaz-Guzman² \\ David M Mannino 3 \\ 'Division of Pulmonary, Allergy \\ and Critical Care Medicine, Duke \\ University, Durham, NC, ${ }^{2}$ Division of \\ Pulmonary, Allergy and Critical Care, \\ University of Alabama, Birmingham, \\ $\mathrm{AL},{ }^{3}$ Department of Preventive \\ Medicine and Environmental Health, \\ University of Kentucky, Lexington, \\ KY, USA
}

\begin{abstract}
Chronic obstructive pulmonary disease (COPD), one of the most common chronic diseases and a leading cause of death, has historically been considered a disease of men. However, there has been a rapid increase in the prevalence, morbidity, and mortality of COPD in women over the last two decades. This has largely been attributed to historical increases in tobacco consumption among women. But the influence of sex on COPD is complex and involves several other factors, including differential susceptibility to the effects of tobacco, anatomic, hormonal, and behavioral differences, and differential response to therapy. Interestingly, nonsmokers with COPD are more likely to be women. In addition, women with COPD are more likely to have a chronic bronchitis phenotype, suffer from less cardiovascular comorbidity, have more concomitant depression and osteoporosis, and have a better outcome with acute exacerbations. Women historically have had lower mortality with COPD, but this is changing as well. There are also differences in how men and women respond to different therapies. Despite the changing face of COPD, care providers continue to harbor a sex bias, leading to underdiagnosis and delayed diagnosis of COPD in women. In this review, we present the current knowledge on the influence of sex on COPD risk factors, epidemiology, diagnosis, comorbidities, treatment, and outcomes, and how this knowledge may be applied to improve clinical practices and advance research.
\end{abstract}

Keywords: chronic obstructive lung disease, sex, smoking, comorbidity, sex bias

\section{Introduction}

Chronic obstructive pulmonary disease (COPD) is one of the most common chronic conditions worldwide, and is now the third-leading cause of death in the US. ${ }^{1}$ Over the past 20 years, COPD-related measures, including prevalence and mortality, have increased more rapidly among women than among men, altering the historical perception that COPD is predominantly a disease of men. ${ }^{2}$ These changes have historically been attributed to the changes in smoking over the last century. Recent evidence suggests that men and women differ in their susceptibility to COPD risk factors, ${ }^{3}$ possibly related to biologic and hormonal mechanisms. In addition, the clinical presentation of COPD, comorbidities, and other factors vary between sexes and may influence response to treatment. We summarize data on how sex influences risk factors, epidemiology, clinical presentation, treatment, and outcomes of COPD, and how this knowledge may help us develop better management strategies.

\section{Sex differences in risk factors of COPD}

Table 1 is a summary of the differences seen in COPD-related risk factors between men and women.
Correspondence: David M Mannino Department of Preventive Medicine and Environmental Health, University of Kentucky, II I Washington Avenue, Lexington, KY 40536, USA

Emaildmannino@uky.edu 
Table I Summary of the influence of sex on COPD risk factors

\begin{tabular}{|c|c|c|}
\hline Risk factors & Male & Female \\
\hline Tobacco use & - Tobacco use peaked in the 1970s in the US among men ${ }^{4}$ & $\begin{array}{l}\text { - Tobacco use peaked in the } 1980 \text { s in the US, and continues } \\
\text { to increase in the developing world } \\
\text { - Women may be more susceptible to tobacco smoking } \\
\text { and develop COPD earlier and with lesser exposure }{ }^{6}\end{array}$ \\
\hline $\begin{array}{l}\text { Occupational } \\
\text { exposures }\end{array}$ & $\begin{array}{l}\text { - Organic dusts from agriculture, mining (coal, heavy } \\
\text { metals), and other industries (metallic fumes like cadmium } \\
\text { and aluminum) }{ }^{14}\end{array}$ & $\begin{array}{l}\text { - Women now working in traditionally male occupations } \\
\text { - Traditionally more exposed to textiles, brassware, ceramics, } \\
\text { and glassware, especially in the developing world }\end{array}$ \\
\hline $\begin{array}{l}\text { Nonoccupational } \\
\text { exposures }\end{array}$ & $\begin{array}{l}\text { - Air pollution is increasing in the developing world, } \\
\text { especially India and the People's Republic of China, } \\
\text { and affects men more due to their mobility } \\
\text { and job types (eg, cab driver) }\end{array}$ & $\begin{array}{l}\text { - Air pollution will be more of a concern as women assume } \\
\text { more male-held jobs; indoor air pollution is a major concern } \\
\text { in the developing world }{ }^{16}\end{array}$ \\
\hline Asthma & $\begin{array}{l}\text { - Asthma is an important comorbidity and risk factor for } \\
\text { COPD }^{17}\end{array}$ & $\begin{array}{l}\text { - Asthmatic women are more susceptible to COPD, and have } \\
\text { poorer quality of life and utilize more health care }{ }^{18}\end{array}$ \\
\hline Genetic factors & - Genetics plays an important role in development of COPD & - Genetically predisposed to develop severe early onset COPD ${ }^{20}$ \\
\hline Infections & $\begin{array}{l}\text { - Infections are important factors for AECOPD } \\
\text { and progression of disease } \\
\text { - Develop lower respiratory infections more frequently } \\
\text { than women }{ }^{22}\end{array}$ & - Upper respiratory infections more common than in men ${ }^{22}$ \\
\hline
\end{tabular}

Abbreviation: AECOPD, acute exacerbations of chronic obstructive pulmonary disease.

\section{Smoking}

Cigarette smoking is the most important risk factor for COPD in the developed world. COPD related to tobacco consumption increased over the past 100 years in most of the developed world as large numbers of men, then women, took up smoking. In the US, cigarette smoking peaked during the 1970s among men and during the 1980s among women. In the developing world, the prevalence of smoking among women is predicted to increase to $20 \%$ by $2025 .{ }^{5}$ Future trends in COPD will reflect this change.

Men and women may have differential susceptibility to tobacco smoke. Women develop more severe COPD at younger ages than men and with lower levels of cigarette exposure. ${ }^{6}$ In the NETT (National Emphysema Treatment Trial) study, women had fewer pack-years of cigarette smoking than men, but had similarly severe COPD. ${ }^{7}$ A 2006 meta-analysis of smoking and COPD by Gan et al found that female smokers had a faster annual decline in forced expiratory volume in 1 second $\left(\mathrm{FEV}_{1}\right)$ than male smokers. ${ }^{8}$ Moreover, Sørheim et al observed that among people with COPD younger than age 60 years, women had a lower mean $\mathrm{FEV}_{1}$ and more severe COPD with less cigarette-smoking exposure. ${ }^{9}$ In that study, women had greater reductions in $\mathrm{FEV}_{1}$ than men when they had fewer than 20 pack-years of exposure, but after 25 pack-years of smoking, the doseresponse relationship of men and women was similar.

The heightened susceptibility to cigarette smoke in women could have several etiologies. First, there may be a genetic predisposition for smoking-related lung damage in certain families that is sex-specific. Silverman et al found a very high prevalence of COPD among women (71.4\%) in a study of 84 probands with severe early onset COPD. In addition, smoking female first-degree relatives of these probands were nearly twice as likely to have airway obstruction and 3.5 times as likely to have severe obstruction than smoking male relatives. ${ }^{10}$ Second, women may have an increased dose-dependent tobacco susceptibility. Women have smaller lungs and airways than men; therefore, the same amount of tobacco smoke results in greater exposure. Furthermore, exposure to secondhand smoke and male/female differences in cigarette-brand preference and inhalational techniques may also be a factor. ${ }^{11}$ Third, there may be hormonally mediated differences in tobacco-smoke metabolism. For example, animal studies demonstrate that cytochrome P450 enzymes are upregulated by estradiol, potentially making female lungs more susceptible to cigarette smoke-related oxidant. ${ }^{12}$

\section{Occupational exposure}

Chronic exposure to occupational dusts is a risk factor for the spectrum of chronic respiratory diseases. ${ }^{13}$ Common occupational exposures linked to COPD include those that come from mining (coal, heavy metals), agriculture (organic dusts), and other industries (metallic fumes like cadmium and aluminum). ${ }^{14}$ These occupations have classically been held by men. However, with the reassignment of sex roles and more single-parent families, a higher number of women are filling those historically male-held jobs. In addition, women, 
especially in the developing world, are working in other dusty industries like the production of textiles, brassware, ceramics, and glassware.

\section{Nonoccupational exposure}

Although air-pollution levels have been decreasing in many parts of the world, these levels remain elevated in some countries like the People's Republic of China and India. This is of particular significance, as recent data suggest that girls experience more reduction in pulmonary function than boys when they have exposure to either environmental air pollution or tobacco smoke. ${ }^{15}$

In addition, indoor air pollution disproportionately affects women, particularly in the developing world. This is primarily due to the common practice of using unprocessed solid fuels, such as wood and dung, for cooking and heating and the reality that cooking is often a task done exclusively by women. ${ }^{16}$

\section{Asthma}

Asthma is a common comorbidity, as well as a risk factor for COPD. People with asthma are at much higher risk of having COPD. ${ }^{17}$ A longitudinal study by Silva et al found that compared to nonasthmatics, active asthmatics had a tenfold-higher risk for acquiring symptoms of chronic bronchitis, a 17-fold higher risk of receiving a diagnosis of emphysema, and a 12-fold higher risk of having COPD, even after adjusting for smoking history and other potential confounders. ${ }^{18}$

The influence of sex on asthma has been studied extensively. Studies show an increased incidence and prevalence of asthma in women, and that asthmatic women have a lower quality of life (QoL) and more utilization of health care compared to their male counterparts, despite similar medical treatment and lung function. ${ }^{19}$ Researchers continue to study the reasons for these differences, including the potential affect of sex hormones, differential perception of airflow obstruction, atopy, heightened bronchial hyperresponsiveness, and medication compliance and technique. The relationship is likely a complex one involving all those factors.

\section{Genetics}

Genetics plays an important role in the development of COPD. The most well-known genetic factor in the development of COPD is the deficiency of the enzyme $\alpha_{1}$-antitrypsin. However, there are a number of other genes that are likely involved in the pathogenesis of COPD. Foreman et al analyzed data from 2,500 subjects in the COPDGene study, a large study that enrolled smokers with and without COPD at 21 clinical centers throughout the US. ${ }^{20}$ Severe, early onset COPD participants were overwhelmingly female (66\%), with higher rates among African American smokers. The COPDGene study has a longitudinal component that will provide new insights into the biologic and sex differences in the genetic predictors of COPD development and progression.

\section{Infections}

Bacterial and viral infections are a major cause of acute exacerbations of COPD, and contribute to the development and progression of COPD. ${ }^{21}$ Sex may influence the development and outcomes of upper and lower respiratory infections, although this has not been studied extensively. An analysis of 84 published studies demonstrated that upper respiratory infections were more common in women, while lower respiratory infections were more common in men. ${ }^{22}$ The same analysis demonstrated that the course of most respiratory infections is more severe in males, leading to higher mortality, especially with community-acquired pneumonia. Similar findings have been reported in other studies, as noted in the outcome sections to follow. The precise reasons behind these differences are not clear, although biologically and hormonally mediated variability in immunity and behavioral differences may be involved.

\section{Sex differences in the prevalence of COPD}

Sex influences COPD in a number of different ways. Table 2 is a summary of these differences in prevalence, comorbidities, and response to different treatment modalities. The measurement and monitoring of the burden of COPD, despite its high prevalence, remains difficult. Prevalence estimates of COPD rely on a number of measures, including self-report, administrative databases, and lung-function testing. In general, higher prevalence is seen among men with analyses of administrative databases, while self-reports show higher prevalence among women. ${ }^{23}$

In the US, between the first and third National Health and Nutrition Examination Surveys (NHANES), the prevalence of spirometrically determined COPD increased among women from 50.8 to 58.2 per 1,000 , while the prevalence decreased among men from 108.1 to 74.3 per $1,000 .^{24}$ Findings from the National Health Interview Survey (NHIS) show that the self-reported prevalence of COPD (chronic bronchitis and emphysema) in the US did not change between 1998 and 2009, and has remained higher among women than among men (Figure 1). ${ }^{25}$ Similar patterns have been observed in other developed countries like Canada, Netherlands, and Austria. ${ }^{26-28}$ 
Table 2 Summary of the influence of sex on the prevalence, diagnosis, and outcomes of chronic obstructive pulmonary disease (COPD)

\begin{tabular}{|c|c|c|}
\hline Outcomes & Male & Female \\
\hline Prevalence & $\begin{array}{l}\text { - Historically more prevalent in males by administrative } \\
\text { database analysis }{ }^{23} \\
\text { - Prevalence decreasing in the US, }{ }^{24} \text { but still rising } \\
\text { in developing countries } \\
\text { - Mostly emphysematous phenotype }{ }^{33,34}\end{array}$ & $\begin{array}{l}\text { - Prevalence is higher by self-report, },^{23,25} \text { and is } \\
\text { increasing in females }{ }^{24} \\
\text { - Mostly chronic bronchitis phenotype } \\
\text { In the US, the number of women diagnosed annually } \\
\text { with emphysema now surpasses that of men as of } \\
2011^{34}\end{array}$ \\
\hline Quality of life & - Poor quality of life compared to general population & $\begin{array}{l}\text { - Poorer quality of life than men and more intense } \\
\text { dyspnea }{ }^{40,44,46}\end{array}$ \\
\hline Diagnosis & $\begin{array}{l}\text { - More likely to be diagnosed with COPD } \\
\text { - Fewer reports of diagnostic delay or reaching physician }\end{array}$ & $\begin{array}{l}\text { - More likely to be diagnosed with asthma }{ }^{50,51} \\
\text { - More diagnostic delay, difficulty reaching physician, } \\
\text { or having adequate time }{ }^{52}\end{array}$ \\
\hline Comorbidities & $\begin{array}{l}\text { - IHD, arrhythmias, alcoholism, renal failure, cancers } \\
\text { more common }{ }^{45,53,54}\end{array}$ & $\begin{array}{l}\text { - Depression, anxiety, osteoporosis, reflux, IBD more } \\
\text { common }{ }^{45,53-57}\end{array}$ \\
\hline $\begin{array}{l}\text { Acute exacerbations } \\
\text { and hospitalizations }\end{array}$ & $\begin{array}{l}\text { - Mortality higher after exacerbation, higher average } \\
\text { number of hospitalizations per year }{ }^{42,75-77}\end{array}$ & - Mortality may be lower after exacerbation ${ }^{42,75-77}$ \\
\hline $\begin{array}{l}\text { Responses } \\
\text { to treatment options }\end{array}$ & $\begin{array}{l}\text { - More attempts at and more sustained quitting } \\
\text { of smoking; nicotine replacement more effective }{ }^{32,59,60} \\
\text { - ICS reduces phlegm more } \\
\text { - Benefits of LTOT may not be as good as in women } \\
\text { - Effects of pulmonary rehabilitation may be more } \\
\text { sustained }\end{array}$ & $\begin{array}{l}\text { - Fewer quit attempts, less sustained quitting, but } \\
\text { better improvement in FEV, with quitting } \\
\text { - ICS may not reduce phlegm as well. }{ }^{63} \text { but } \\
\text { deterioration may be worse on stopping; }{ }^{65} \text { chronic } \\
\text { macrolide therapy may be more effective }{ }^{66} \\
\text { - More emotional and psychosocial benefits } \\
\text { from pulmonary rehabilitation }{ }^{73}\end{array}$ \\
\hline Mortality & - Declining over last few decades ${ }^{23}$ & $\begin{array}{l}\text { - Increasing over last few decades; and predicted to } \\
\text { continue to rise: }{ }^{23} \text { more women have died than } \\
\text { men from COPD in the US since } 2000^{23}\end{array}$ \\
\hline
\end{tabular}

Abbreviations: IHD, ischemic heart disease; IBD, inflammatory bowel disease; FEV ${ }_{1}$, forced expiratory volume in I second; ICS, inhaled corticosteroids; LTOT, long-term oxygen therapy.

In the developing world, diagnosed COPD remains higher among men than among women; ${ }^{29-31}$ while some of these differences may reflect a sex bias in the diagnosis of COPD, the future will likely see increasing prevalence among women as more take up smoking and work in traditionally male occupations. ${ }^{32}$

\section{Sex differences in the expression of COPD}

There are also phenotypic differences between women and men in the expression of COPD, which might help explain some of the prevalence differences noted earlier. In 1987 ,

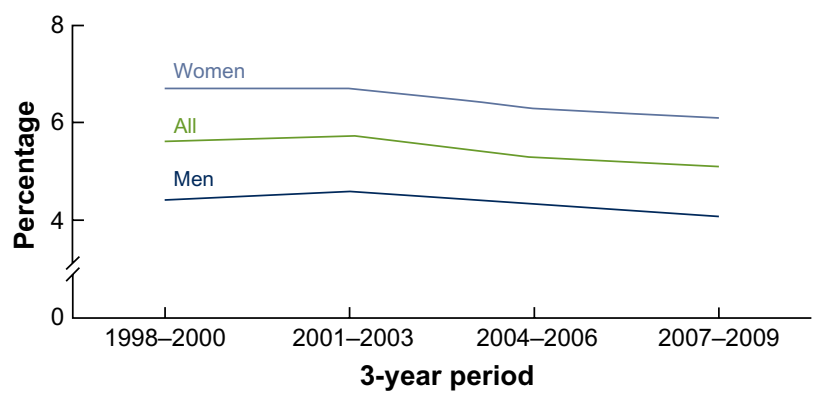

Figure I Prevalence of self-reported chronic obstructive pulmonary disease among adults aged 18 and over: US, 1998-2009.

Note: Data from Akinbami LJ, Liu X. Chronic obstructive pulmonary disease among adults aged 18 and over in the United States, 1998-2009. 2011. Available from: http://www.cdc.gov/nchs/data/databriefs/db63.htm. ${ }^{25}$
Burrows et al suggested that sex dimorphism may be present in COPD when they described two types of COPD: emphysema and chronic asthmatic bronchitis. ${ }^{33}$ People with emphysema were more likely to be men, experienced more rapid decline in pulmonary function, and had a higher mortality rate. People with chronic asthmatic bronchitis were more likely to be women, experienced less rapid decline in pulmonary function, and had a lower mortality rate. NHIS data similarly suggest that chronic bronchitis is more common among women, and emphysema is traditionally more common among men, although since 2011 more women in the US have been diagnosed with emphysema than men. ${ }^{34}$ Radiologic and histologic data also show similar findings, with women having less severe emphysema but thicker airway walls and smaller airway lumens. ${ }^{35}$

An interesting observation with regard to sex is seen in COPD among never-smokers. About $15 \%-30 \%$ of all people who have evidence of COPD are never-smokers. Of this group, nearly $80 \%$ are women, suggesting that women may be more susceptible to nonsmoking-related factors. ${ }^{36}$ In one prospective study of COPD among never-smokers, sputum eosinophilia was elevated in one group and sputum neutrophil count was elevated in another. ${ }^{37}$ The group with 
the neutrophilia had a higher prevalence of organ-specific autoimmune disease and autoantibodies, including thyroid disease. In another study, changes in the bronchoalveolar lavage-cell proteome were found in female but not male patients. ${ }^{38}$ These observations suggest that increased responsiveness of the female immune system may be responsible for some sex-related differences. ${ }^{39}$

Women who have COPD are more likely to report dyspnea $^{40,41}$ and less likely to report the production of phlegm. ${ }^{40,42}$ In addition, women report higher intensity of dyspnea despite fewer pack-years of smoking and similar degrees of pulmonary impairment. ${ }^{41}$ A recent Spanish study showed that women reported less phlegm than men but a similar level of cough, dyspnea, and wheezing. ${ }^{43}$ An analysis of the PLATINO (Proyecto Latinoamericano de Investigación en Obstrucción Pulmonar) cohort showed that dyspnea was more common among women both with and without COPD. ${ }^{44}$ In the ECLIPSE (Evaluation of COPD Longitudinally to Identify Predictive Surrogate Endpoints) cohort, when stratified by COPD-severity category, men and women had a similar age, but women had less smoking exposure, lower body mass index and fat-free mass index, and more exacerbations than men. ${ }^{45}$ In the TORCH (Towards a Revolution for COPD Health) study, women reported more exacerbations and worse dyspnea. ${ }^{46}$ The Euroscop study demonstrated that $\mathrm{FEV}_{1}$ as well as change over time correlated with prevalence, remission, and incidence of symptoms in men. This study suggests that symptoms are a good predictor of disease status and/or underlying disease activity, particularly among men. ${ }^{47}$

The reasons behind differences in clinical expression of COPD between men and women are likely multifactorial. Becklake and Kauffmann suggested that societal concepts of athleticism may cause men to report less breathlessness than women; ${ }^{48}$ others have suggested that sociocultural factors may result in women being less likely to report the production of sputum or phlegm. ${ }^{23}$ Some physiologic data suggest that fat-free body mass, which is lower in women with COPD, is related to a lower diffusion capacity and more dyspnea. ${ }^{49}$

\section{Sex bias in the diagnosis of COPD}

Health care providers are more likely to diagnose COPD in men than women. This has important implications in the care and outcome of these patients. Two studies assessed sex bias in the diagnosis of COPD among health care workers in recent years. In 2001 in the US and Canada, Chapman et al had a study published ${ }^{50}$ that was replicated in Spain by Miravitlles et al in 2006. ${ }^{51}$ The Confronting COPD Survey also found that after adjusting for age, pack-years, country, and dyspnea scores, women were less likely to have had spirometry but more likely to have had smoking-cessation advice. ${ }^{40}$ In another recent study of more than 3,500 patients by Ancochea et al, $73 \%$ of patients with spirometric COPD criteria were underdiagnosed clinically, and this percentage varied by sex, being $30 \%$ more frequent among women (86.0\%) than among men (67.6\%). ${ }^{43}$ Also, a study looking at the perception of COPD found that women were more likely to report COPD diagnostic delay, difficulty reaching the physician, and not being able to spend sufficient time with the physician. ${ }^{52}$ Together, these data suggest that women with COPD are underdiagnosed and less likely to be controlled and content with their COPD treatment.

\section{Sex differences in comorbidities}

Patients with COPD often have coexisting medical conditions that contribute to morbidity and mortality. Although sex differences in comorbidities are relatively understudied, men and women differ in their patterns of comorbid diseases, which might explain, in part, the differences in outcomes between the two sexes. In the ECLIPSE cohort, cardiovascular comorbidity and diabetes were less common among women, whereas osteoporosis, inflammatory bowel disease, reflux, and depression requiring treatment were more common. ${ }^{45}$ In a European study, women with COPD had less ischemic heart disease and alcoholism, but more chronic heart failure, osteoporosis, and diabetes mellitus. ${ }^{53} \mathrm{~A}$ recent Swedish study of oxygen-dependent COPD patients showed that men had more arrhythmia, ischemic heart disease, cancer and renal failure, fewer mental disorders, and less osteoporosis, hypertension, and rheumatoid arthritis than women. ${ }^{54}$ Women also had more anxiety and depression and worse symptom-related QoL than men. ${ }^{55,56}$ Symptoms and QoL measures may be more important determinants of depression in women with COPD than physiologic and biologic measures. ${ }^{57}$

\section{Sex-related differences in treatment options for COPD Smoking cessation}

Smoking cessation is the only intervention documented to slow lung-function decline. ${ }^{58}$ Women are not only more susceptible to adverse effects of tobacco smoking but also they may have more benefits upon successfully quitting smoking. This was demonstrated in the Lung Health Study that showed that women who remained nonsmokers had an average improvement in their $\mathrm{FEV}_{1} \%$ predicted during the first year that was 2.5 times greater than the improvement 
seen in their male counterparts. ${ }^{59}$ However, women may have more difficulty quitting and have a lower long-term success rate of smoking cessation than men do; this may be, in part, due to less symptomatic benefit upon quitting among women. ${ }^{32}$ Recent population data from the US, Canada and the UK suggest similar rates of successful tobacco cessation between sexes. ${ }^{60}$ Older pharmacologic therapy with nicotine replacement was more beneficial among men, whereas the newer agents bupropion and varenicline seem to be equally effective in women and men. ${ }^{32}$

\section{Pharmacologic management of COPD}

There are few data on sex differences in different therapies for COPD, because most studies of pharmacologic agents have not been designed to assess treatment in men versus women and most trials have enrolled more males than females. ${ }^{3}$ For example, little is known about how differences in lung anatomy and physiology of males and females may affect dosage, delivery, and effectiveness of inhaled medications. Based on current studies, there is minimal known effect of sex on efficacy and adverse events of current agents. One study found no male/female differences in the efficacy of salmeterol/ fluticasone combination therapy on predose $\mathrm{FEV}_{1}$, exacerbation rate, or QoL scores. ${ }^{61}$ Another study demonstrated that the effects of tiotropium on lung function, symptoms, and QoL were similar in men and women. ${ }^{62}$ Budesonide led to a reduction in phlegm among men but not women in the Euroscop study. ${ }^{63,64}$ The probability of respiratory deterioration (either symptomatic or exacerbations) when stopping inhaled steroids is higher among women than among men. ${ }^{65}$ In a recent study of azithromycin for the prevention of acute exacerbations of COPD, a subgroup analysis showed a nonstatistical difference favoring women. ${ }^{66}$ Large and better-designed trials are necessary to determine whether clinically meaningful sex differences exist in the pharmacotherapy of COPD.

There may also be sex differences in prescribing habits of providers, as well as compliance with medications between men and women. Dales et al found that among patients with mild-to-moderate COPD, the proportion of females on respiratory medications was twice that of males; this difference was not seen in severe COPD. ${ }^{67}$ On the other hand, Sestini et al found that men with COPD were more likely than women to be on the "new" dry-powder inhalers versus metered-dose inhalers. ${ }^{68}$

\section{Long-term oxygen therapy}

Long-term oxygen therapy (LTOT) improves survival among hypoxemic patients with COPD, but the impact of sex on
LTOT has been mixed. A meta-analysis of LTOT showed that women on LTOT had a survival advantage over men. ${ }^{69}$ However, Machado et al reported that in a cohort of patients with COPD receiving LTOT, survival was significantly worse among women. ${ }^{70}$ Discrepancies between these studies may be due to patient population and analytical approaches, and the criteria for indications to start LTOT.

\section{Vaccination}

Studies on sex differences in vaccination are scant. One study from Israel showed that women were less likely to receive influenza and pneumococcal vaccinations, ${ }^{71}$ but it is not clear that this finding can be extrapolated to other countries and cultures.

\section{Pulmonary rehabilitation}

A multidisciplinary pulmonary rehabilitation program should be part of the therapy of all patients with COPD, and should include components of exercise training, nutritional counseling, and patient education. Foy et al demonstrated that after 3 months of exercise therapy, both men and women reported similar improvements in health-related QoL (HRQoL) measures; after 18 months, however, continued benefits were seen in men but not in women. ${ }^{72}$ Haggerty et al assessed improvements in outcomes among 164 subjects (54\% female) in pulmonary rehabilitation. ${ }^{73}$ They found that women experienced larger improvements in the mastery and emotion subscales of the Chronic Respiratory Disease Questionnaire (CRDQ) and the psychosocial subscale of the Pulmonary Function Status Scale (PFSS); however, all other outcomes (other subscales of the CRDQ and the PFSS, and 6-minute walk distance) were similar between men and women.

\section{Influence of sex in outcomes of COPD Differences in morbidity, acute exacerbations, and hospitalizations}

COPD is a major source of morbidity globally. The difference in prevalence of COPD, diagnosis, comorbidities, and outcomes with treatment in the two sexes has been discussed in the prior sections. Females also have a decreased HRQoL related to COPD. In both the PLATINO and TORCH cohorts, more females identified their health as fair to poor compared to males, and currently smoking females had more severe disease than males. ${ }^{44,46}$ In addition, the factors determining HRQoL for men and women with COPD may differ by sex. In one study among men, the total SGRQ score was predicted 

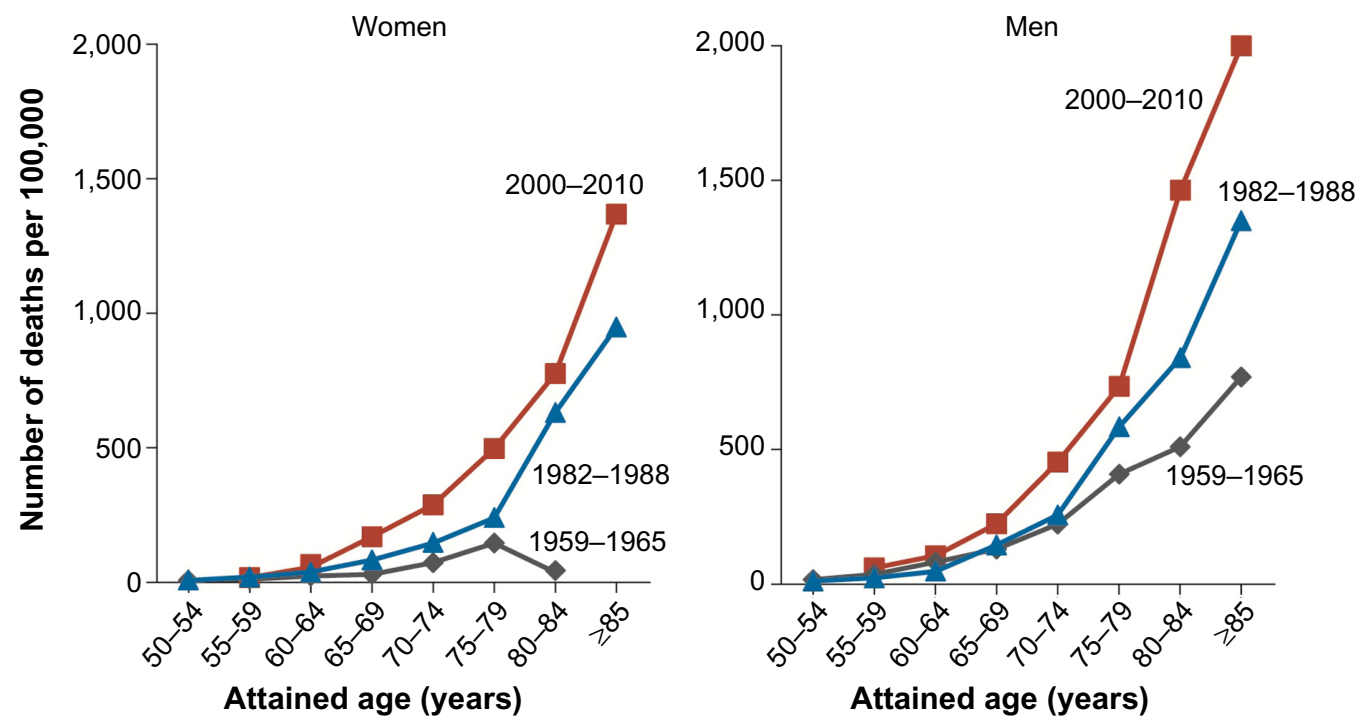

Figure 2 Changes in rates of death from chronic obstructive pulmonary disease over time among current female and male smokers in three time periods. Note: Reproduced from N Engl J Med, Thun MJ, Carter BD, Feskanich D, et al. 50-year trends in smoking-related mortality in the United States. 20I 3;368:35 I-364. Copyright (C)2013 Massachusetts Medical Society. Reprinted with permission from Massachusetts Medical Society. ${ }^{80}$

by dyspnea, exercise capacity, degree of hyperinflation, and comorbidity, whereas among women the only predictors were dyspnea and oxygenation status. ${ }^{74}$

Men and women differ in the outcomes of acute exacerbations and hospitalizations of COPD, with women generally having a survival advantage. In one study of COPD exacerbations in the emergency department, Cydulka et al found higher relapse rates among men despite similar levels of care provided in the hospital. ${ }^{42}$ However, they also found that women were less likely to self-medicate with anticholinergic agents, and were less likely to seek emergency care within the first 24 hours of exacerbation. Cao et al found among 186 patients with COPD in Singapore that men had more hospital admissions in a year for COPD exacerbations than women. ${ }^{75}$ In a recent analysis of over 40,000 people in Canada, Gonzalez et al found that men had an increased risk of death and hospitalization for COPD. ${ }^{76}$ Patil and colleagues also found an increased risk for in-hospital mortality among men admitted for an acute exacerbation of COPD. ${ }^{77}$

\section{Differences in mortality}

Between 1990 and 2010, COPD became the third-leading cause of death in the US. Death rates for COPD declined among US men between 1999 (57.0 per 100,000) and 2006 (46.4 per 100,000), whereas there was no significant change in death rates among women (35.3 per 100,000 in 1999 and 34.2 per 100,000 in 2006). In 2000, the absolute number of women dying from COPD surpassed the number of men, although the age-adjusted COPD death rates for men were $30 \%$ higher than those rates for women. ${ }^{23}$
In 2009, de Torres et al showed that after controlling for disease severity, women had significantly better survival than men. ${ }^{78}$

A recent assessment of changes in mortality rates due to COPD in the cohorts from NHANES I and NHANES III in the US showed a smaller decrease in the mortality rate among women with moderate or severe COPD than among men $(3.0 \%$ versus $17.8 \%) .{ }^{79}$ An analysis of smokingrelated mortality in the US evaluated temporal trends in sex-specific smoking-related mortality across three time periods (1959-1965, 1982-1988, 2000-2010) in seven large cohorts. ${ }^{80}$ In the "contemporary" cohort (2000-2010), male and female current smokers had similar relative risks for mortality from COPD (26.61 for men, 22.35 for women), with these relative risks representing almost a doubling of risk compared to the 1982-1988 time period (Figure 2). The survival advantage that women with COPD have historically had has been slowly diminishing in recent years. Finally, in a recent analysis of the BOLD (Burden of Obstructive Lung Disease) cohort, spirometric restriction was more predictive of increased mortality risk than airflow obstruction in both the sexes, with worse mortality seen in lower-income groups. ${ }^{81}$

\section{Conclusion}

The influence of sex on COPD risk and outcomes is due to a combination of both environmental/behavioral factors and genetic/biophysiologic factors. In addition, the roles that women play in society, along with cultural norms and expectations, are changing rapidly in both the developed and 
developing worlds. Identifying the reasons and mechanisms behind those factors, as well as the sex differences in the pattern of comorbidities, exacerbations, and therapeutic response, may lead to improved therapies and outcomes.

\section{Disclosure}

DMM has served on advisory boards for Boehringer Ingelheim, Pfizer, GlaxoSmithKline, Sepracor, Astra-Zeneca, Novartis, and Ortho Biotech, and has received research grants from Astra-Zeneca, GlaxoSmithKline, Novartis and Pfizer. The other authors report no conflicts of interest in this work.

\section{References}

1. Murphy SL, Xu J, Kochanek KD. Deaths: Final Data for 2010. Nat Vital Stat Rep. 2013;61:1-117.

2. World Health Organization. World Health Statistics: 2008. Geneva: WHO; 2008. Available from: http:/www.who.int/whosis/whostat/ EN_WHS08_Full.pdf. Accessed June 1, 2014.

3. US Department of Health and Human Services. The Health Consequences of Smoking - 50 Years of Progress. A Report of the Surgeon General - Executive Summary. Rockville (MD): HSS; 2014. Available from: http://www.surgeongeneral.gov/library/reports/50years-of-progress/exec-summary.pdf. Accessed June 2, 2014.

4. Burns D, Major J, Shanks T. Changes in number of cigarettes smoked per day: cross-sectional and birth cohort analyses using NHIS. In: Ruppert W, editor. Those Who Continue to Smoke: Is Achieving Abstinence Harder and Do We Need to Change Our Interventions? Collingdale (PA): Diane; 2004:83-99.

5. Mackay J, Amos A. Women and tobacco. Respirology. 2003;8: 123-130.

6. Murray CJ, Lopez AD. Alternative projections of mortality and disability by cause 1990-202: Global Burden of Disease Study. Lancet. 1997;349:1498-1504.

7. Martinez FJ, Curtis JL, Sciurba FC, et al. Sex differences in severe pulmonary emphysema. Am J Respir Crit Care Med. 2007;176: $243-252$.

8. Gan WQ, Man SF, Postma DS, Camp P, Sin DD. Female smokers beyond the perimenopausal period are at increased risk of chronic obstructive pulmonary disease: a systematic review and meta-analysis. Respir Res. 2006;7:52.

9. Sørheim IC, Johannessen A, Gulsvik A, Bakke PS, Silverman EK, DeMeo DL. Gender differences in COPD: are women more susceptible to smoking effects than men? Thorax. 2010;65:480-485.

10. Silverman E, Weiss S, Drazen J, et al. Gender-related differences in severe, early-onset chronic obstructive pulmonary disease. Am J Respir Crit Care Med. 2000;162:2152-2158.

11. Han MK, Postma D, Mannino D, et al. Gender and chronic obstructive pulmonary disease: why it matters. Am J Respir Crit Care Med. 2007;176:1179-1184.

12. Van Winkle LS, Gunderson AD, Shimizu JA, Baker GL, Brown CD. Gender differences in naphthalene metabolism and naphthaleneinduced acute lung injury. Am J Physiol Lung Cell Mol Physiol. 2002;282:L1122-L1134.

13. Eisner MD, Anthonisen N, Coultas D, et al. An official American Thoracic Society public policy statement: Novel risk factors and the global burden of chronic obstructive pulmonary disease. Am J Respir Crit Care Med. 2010;182:693-718.

14. Diaz-Guzman E, Aryal S, Mannino DM. Occupational chronic obstructive pulmonary disease: an update. Clin Chest Med. 2012;33: $625-636$.
15. Sin DD, Cohen SB, Day A, Coxson H, Paré PD. Understanding the biological differences in susceptibility to chronic obstructive pulmonary disease between men and women. Proc Am Thorac Soc. 2007;4: 671-674.

16. Varkey AB. Chronic obstructive pulmonary disease in women: exploring gender differences. Curr Opin Pulm Med. 2004;10:98-103.

17. Diaz-Guzman E, Mannino DM. Airway obstructive diseases in older adults: from detection to treatment. J Allergy Clin Immunol. 2010;126:702-709.

18. Silva GE, Sherrill DL, Guerra S, Barbee RA. Asthma as a risk factor for COPD in a longitudinal study. Chest. 2004;126:59-65.

19. Kynyk JA, Mastronarde JG, McCallister JW. Asthma, the sex difference. Curr Opin Pulm Med. 2011;17:6-11.

20. Foreman MG, Zhang L, Murphy J, et al. Early-onset chronic obstructive pulmonary disease is associated with female sex, maternal factors, and African American race in the COPDGene Study. Am J Respir Crit Care Med. 2011;184(4):414-420.

21. Global initiative for chronic Obstructive Lung Disease (GOLD). Global Strategy for the Diagnosis, Management, and Prevention of Chronic Obstructive Pulmonary Disease. Bethesda (MD): GOLD; 2013.

22. Falagas ME, Mourtzoukou EG, Vardakas KZ. Sex differences in the incidence and severity of respiratory tract infections. Respir Med. 2007;101:1845-1863.

23. Camp PG, Goring SM. Gender and the diagnosis, management, and surveillance of chronic obstructive pulmonary disease. Proc Am Thorac Soc. 2007;4:686-691.

24. Mannino DM, Homa DM, Akinbami LJ, Ford ES, Redd SC. Chronic obstructive pulmonary disease surveillance-United States, 1971-2000. MMWR Surveill Summ. 2002;51:1-16.

25. Akinbami LJ, Liu X. Chronic obstructive pulmonary disease among adults aged 18 and over in the United States, 1998-2009. 2011. Available from: http://www.cdc.gov/nchs/data/databriefs/db63.htm. Accessed August 4, 2014.

26. Gershon AS, Wang C, Wilton AS, Raut R, To T. Trends in chronic obstructive pulmonary disease prevalence, incidence, and mortality in Ontario, Canada, 1996 to 2007: a population-based study. Arch Intern Med. 2010;170:560-565.

27. Bischoff EW, Schermer TR, Bor H, Brown P, van Weel C, van den Bosch WJ. Trends in COPD prevalence and exacerbation rates in Dutch primary care. Br J Gen Pract. 2009;59:927-933.

28. Schirnhofer L, Lamprecht B, Vollmer WM, et al. COPD prevalence in Salzburg, Austria: results from the Burden of Obstructive Lung Disease (BOLD) study. Chest. 2007;131:29-36.

29. Menezes AM, Perez-Padilla R, Jardim JR, et al. Chronic obstructive pulmonary disease in five Latin American cities (the PLATINO study): a prevalence study. Lancet. 2005;366:1875-1881.

30. Bhome AB. COPD in India: iceberg or volcano? J Thorac Dis. 2012;4:298-309.

31. Zhong N, Wang C, Yao W, et al. Prevalence of chronic obstructive pulmonary disease in China: a large, population-based survey. Am J Respir Crit Care Med. 2007;176:753-760.

32. Han MK, Postma D, Mannino D, et al. Gender and chronic obstructive pulmonary disease: why it matters. Am J Respir Crit Care Med. 2007; 176:1179-1184.

33. Burrows B, Boom J, Traver G, Cline M. The course and prognosis of different forms of chronic airways obstruction in a sample from the general population. $N$ Engl J Med. 1987;317:1209-1214.

34. Centers for Disease Control and Prevention. National Center for Health Statistics: National Health Interview Survey raw data, 2011. Available from: http://www.cdc.gov/nchs/nhis/nhis_2011_data_release.htm. Accessed September 9, 2014.

35. Martinez F, Curtis J, Sciurba F, et al. Sex differences in severe pulmonary emphysema. Am J Respir Crit Care Med. 2007;176:243-252.

36. Celli BR, Halbert RJ, Nordyke RJ, et al. COPD in never smokers: a significant problem? Airway obstruction in never smokers: results from the Third National Health and Nutrition Examination Survey. Am J Med. 2005;118:1364-1372. 
37. Birring $\mathrm{S}$, Brightling $\mathrm{C}$, Bradding $\mathrm{P}$, et al. Clinical, radiologic and induced sputum features of chronic obstructive pulmonary disease in nonsmokers: a descriptive study. Am J Respir Crit Care Med. 2002;166: 1078-1083.

38. Kohler M, Sandberg A, Kjellqvist S, et al. Gender differences in the bronchoalveolar lavage cell proteome of patients with chronic obstructive pulmonary disease. J Allergy Clin Immunol. 2013;131:743-751.

39. Aryal S, Diaz-Guzman E, Mannino DM. COPD and gender differences: an update. Transl Res. 2013;162:208-218.

40. Watson L, Vestbo J, Postma DS, et al. Gender differences in the management and experience of chronic obstructive pulmonary disease. Respir Med. 2004;98:1207-1213.

41. de Torres JP, Casanova C, Hernández C, Abreu J, Aguirre-Jaime A, Celli BR. Gender and COPD in patients attending a pulmonary clinic. Chest. 2005;128:2012-2016.

42. Cydulka RK, Rowe BH, Clark S, Emerman CL, Rimm AR, Camargo CA. Gender differences in emergency department patients with chronic obstructive pulmonary disease exacerbations. Acad Emerg Med. 2005;12:1173-1179.

43. Ancochea J, Miravitlles M, García-Río F, et al. Under-diagnosis of chronic obstructive pulmonary disease in women: quantification of the problem, determinants and proposed actions. Arch Bronconeumol. 2013;49:223-229.

44. Lopez Varela MV, Montes de Oca M, Halbert RJ, et al. Sex-related differences in COPD in five Latin American cities: the PLATINO study. Eur Respir J. 2010;36:1034-1041.

45. Agusti A, Calverley PM, Celli B, et al. Characterization of COPD heterogeneity in the ECLIPSE cohort. Respir Res. 2010;11:122.

46. Celli B, Vestbo J, Jenkins CR, et al. Sex differences in mortality and clinical expressions of patients with chronic obstructive pulmonary disease. The TORCH experience. Am J Respir Crit Care Med. 2011;183:317-322.

47. Watson L, Vonk JM, Lofdahl CG, et al. Predictors of lung function and its decline in mild to moderate COPD in association with gender: results from the Euroscop study. Respir Med. 2006;100:746-753.

48. Becklake MR, Kauffmann F. Gender differences in airway behavior over the human life span. Thorax. 1999;54:1119-1138.

49. Verhage TL, Heijdra Y, Molema J, Vercoulen J, Dekhuijzen R. Associations of muscle depletion with health status. Another gender difference in COPD? Clin Nutr. 2011;30:332-338.

50. Chapman KR, Tashkin DP, Pye DJ. Gender bias in the diagnosis of COPD. Chest. 2001;119:1691-1695.

51. Miravitlles M, de la Roza C, Naberan K, et al. [Attitudes toward the diagnosis of chronic obstructive pulmonary disease in primary care]. Arch Bronconeumol. 2006;42:3-8. Spanish.

52. Martinez CH, Raparla S, Plauschinat CA, et al. Gender differences in symptoms and care delivery for chronic obstructive pulmonary disease. J Womens Health (Larchmt). 2012;21:1267-1274.

53. Almagro P, López García F, Cabrera F, et al. Comorbidity and genderrelated differences in patients hospitalized for COPD. The ECCO study. Respir Med. 2010;104:253-259.

54. Ekström MP, Jogréus C, Ström KE. Comorbidity and sex-related differences in mortality in oxygen-dependent chronic obstructive pulmonary disease. PLoS One. 2012;7:e35806.

55. Di Marco F, Verga M, Reggente M, et al. Anxiety and depression in COPD patients: the roles of gender and disease severity. Respir Med. 2006;100:1767-1774.

56. Gudmundsson G, Gislason T, Janson C, et al. Risk factors for rehospitalisation in COPD: role of health status, anxiety and depression. Eur Respir J. 2005;26:414-419.

57. Hanania NA, Müllerova H, Locantore NW, et al. Determinants of depression in the ECLIPSE chronic obstructive pulmonary disease cohort. Am J Respir Crit Care Med. 2011;183:604-611.

58. Pauwels RA, Buist AS, Ma P, Jenkins CR, Hurd SS. Global strategy for the diagnosis, management, and prevention of chronic obstructive pulmonary disease: National Heart, Lung, and Blood Institute and World Health Organization Global Initiative for Chronic Obstructive Lung Disease (GOLD): executive summary. Respir Care. 2001;46:798-825.
59. Scanlon PD, Connett JE, Waller LA, Altose MD, Bailey WC, Buist AS. Smoking cessation and lung function in mild-to-moderate chronic obstructive pulmonary disease. The Lung Health Study. Am J Respir Crit Care Med. 2000;161:381-390.

60. Jarvis MJ, Cohen JE, Delnevo CD, Giovino GA. Dispelling myths about gender differences in smoking cessation: population data from the USA, Canada and Britain. Tob Control. 2013;22:356-360.

61. Vestbo J, Soriano JB, Anderson JA, Calverley P, Pauwels R, Jones P. Gender does not influence the response to the combination of salmeterol and fluticasone propionate in COPD. Respir Med. 2004;98: 1045-1050.

62. O’Donnell DE, Flüge T, Gerken F, et al. Effects of tiotropium on lung hyperinflation, dyspnoea and exercise tolerance in COPD. Eur Respir J. 2004;23:832-840.

63. Watson L, Schouten JP, Lofdahl CG, Pride NB, Laitinen LA, Postma DS. Predictors of COPD symptoms: does the sex of the patient matter? Eur Respir J. 2006;28:311-318.

64. Hubbard RB, Smith CJ, Smeeth L, Harrison TW, Tattersfield AE. Inhaled corticosteroids and hip fracture: a population-based case-control study. Am J Respir Crit Care Med. 2002;166:1563-1566.

65. Schermer TR, Hendriks AJ, Chavannes NH, et al. Probability and determinants of relapse after discontinuation of inhaled corticosteroids in patients with COPD treated in general practice. Prim Care Respir J. 2004; 13:48-55.

66. Albert RK, Connett J, Bailey WC, et al. Azithromycin for prevention of exacerbations of COPD. N Engl J Med. 2011;365:689-698.

67. Dales RE, Mehdizadeh A, Aaron SD, Vandemheen KL, Clinch J. Sex differences in the clinical presentation and management of airflow obstruction. Eur Respir J. 2006;28:319-322.

68. Sestini P, Cappiello V, Aliani M, et al. Prescription bias and factors associated with improper use of inhalers. J Aerosol Med. 2006;19:127-136.

69. Crockett AJ, Cranston JM, Moss JR, Alpers JH. Survival on long-term oxygen therapy in chronic airflow limitation: from evidence to outcomes in the routine clinical setting. Intern Med J. 2001;31:448-454.

70. Machado MC, Krishnan JA, Buist SA, et al. Sex differences in survival of oxygen-dependent patients with chronic obstructive pulmonary disease. Am J Respir Crit Care Med. 2006;174:524-529.

71. Schwartz AW, Clarfield AM, Doucette J, et al. Disparities in pneumococcal and influenza immunization among older adults in Israel: a cross-sectional analysis of socio-demographic barriers to vaccination. Prev Med. 2013;56:337-340.

72. Foy CG, Rejeski WJ, Berry MJ, Zaccaro D, Woodard CM. Gender moderates the effects of exercise therapy on health-related quality of life among COPD patients. Chest. 2001;119:70-76.

73. Haggerty MC, Stockdale-Woolley R, Zuwallack R. Functional status in pulmonary rehabilitation participants. J Cardiopulm Rehabil. 1999; 19:35-42.

74. de Torres Tajes JP, Casanova C, Hernández C, et al. Gender associated differences in determinants of quality of life in patients with COPD: a case series study. Health Qual Life Outcomes. 2006;4:72.

75. Cao Z, Ong KC, Eng P, Tan WC, Ng TP. Frequent hospital readmissions for acute exacerbation of COPD and their associated factors. Respirology. 2006;11:188-195.

76. Gonzalez AV, Suissa S, Ernst P. Gender differences in survival following hospitalisation for COPD. Thorax. 2011;66:38-42.

77. Patil SP, Krishnan JA, Lechtzin MD, Diette GB. In-hospital mortality following acute exacerbations of chronic obstructive pulmonary disease. Arch Intern Med. 2003;163:1180-1186.

78. de Torres JP, Cote C, López MV, et al. Sex differences in mortality in patients with COPD. Eur Respir J. 2009;33:528-535.

79. Ford ES, Mannino DM, Zhao G, Li C, Croft JB. Changes in mortality among US adults with COPD in two national cohorts recruited from 1971-1975 and 1988-1994. Chest. 2012;141:101-110.

80. Thun MJ, Carter BD, Feskanich D, et al. 50-year trends in smoking-related mortality in the United States. N Engl J Med. 2013;368:351-364.

81. Burney P, Jithoo A, Kato B, et al. Chronic obstructive pulmonary disease mortality and prevalence: the associations with smoking and poverty - a BOLD analysis. Thorax. 2014;69:465-473. 
International Journal of COPD

Dovepress

\section{Publish your work in this journal}

The International Journal of COPD is an international, peer-reviewed journal of therapeutics and pharmacology focusing on concise rapid reporting of clinical studies and reviews in COPD. Special focus is given to the pathophysiological processes underlying the disease, intervention programs, patient focused education, and self management protocols.

This journal is indexed on PubMed Central, MedLine and CAS. The manuscript management system is completely online and includes a very quick and fair peer-review system, which is all easy to use. Visit http://www.dovepress.com/testimonials.php to read real quotes from published authors.

Submit your manuscript here: http://www.dovepress.com/international-journal-of-copd-journal 